\begin{tabular}{|c|c|}
\hline $\begin{array}{l}\text { ONIVERITY OF } \\
\text { OXFORD }\end{array}$ & $\begin{array}{l}\text { Department of } \\
\text { Politics and } \\
\text { International } \\
\text { Relations }\end{array}$ \\
\hline
\end{tabular}

\title{
The 'Mirage' of Social Justice: Hayek Against (and For) Rawls
}

\author{
Andrew Lister \\ Oliver Smithies Lecture, Trinity Term; May 10, 2011 \\ Balliol College, Oxford
}

andrew.lister@politics.ox.ac.uk

\section{CSSJ Working Papers Series, SJ017 \\ June 2011}

Centre for the Study of Social Justice

Department of Politics and International Relations

University of Oxford

Manor Road, Oxford OX13UQ

United Kingdom

Tel: +44 $1865278703 \quad$ Fax: +44 1865278725

http://social-justice.politics.ox.ac.uk 
This is the revised and slightly expanded text of a public lecture. Comments are most welcome: andrew.lister@queensu.ca

\section{Introduction}

Friedrich Hayek has been one of the inspirations for what is sometimes called "neoliberalism." In 1947 he helped organize the Mont Pelerin Society, a free market group opposed to socialism, and in 1955 played a role in founding the Institute for Economic Affairs, another free-market think tank. The Institute arranged a meeting between Hayek and Thatcher just after she became leader of the Conservative party in $1975 .^{1}$ Later that year, Thatcher is reported to have responded to a suggestion from a party strategist that the Conservatives should adopt a moderate, pragmatic approach, by holding up Hayek's Constitution of Liberty and declaring "this is what we believe." 2

In the 2nd volume Law, Legislation and Liberty, published in 1976, Hayek called the idea of social justice a "mirage." 3 In case there might be any confusion about his view, he also called social justice a "will-o-the-wisp" (I: 142; 67; II: 99) ${ }^{4}$, an "empty formula,"" "strictly," "necessarily," and "entirely" "empty and meaningless" (II: 68, 69, xi); a phrase that "meant nothing at all" (II: xii, 33), that "has no meaning whatsoever,"6 a vacuous concept (II: 64, 97); "a quasi-religious belief with no content whatsoever" (II: xi-xii), a "primitive...

1 John Ranelagh, Thatcher's People. An Insider's Account of the Politics, the Power and the Personalities (Harper Collins, 1991), 174-76.

2 Ranelagh, Thatcher's People. An Insider's Account of the Politics, the Power and the Personalities, ix. Steven Lukes remarks on the influence Hayek seems to have had on Thatcher, in particular on her comment that "there is no such thing as society;" Steven Lukes, "Social Justice: The Hayekian Challenge," Critical Review 11, no. 1 (1997), 66.

3 Friedrich A. von Hayek, Law, Legislation, and Liberty : A New Statement of the Liberal Principles of Justice and Political Economy, New pbk. ed. ed. (London: Routledge and Kegan Paul, 1982). Henceforward, all references to this work will be made parenthetically in the text, with Roman numerals indicating the volume in question.

4 In-text citations are by volume and page number, from Hayek, Law, Legislation, and Liberty. Other works by Hayek are cited in the footnotes.

5 Friedrich A. von Hayek, Social Justice, Socialism and Democracy (Sydney, Australia: The Centre for Independent Studies, 1979), 3.

$6 \quad$ Hayek, Social Justice, Socialism and Democracy, 3. 
anthropomorphism" (II: 62, 75), or "atavism,"7 a "superstition" (II: 66), like believing in witches or the philosopher's stone (II: 75), or a "hollow incantation" (II: xii), like "open sesame" (II: 67). He thought that social justice was a particularly dangerous superstition, describing it as "that incubus which today makes fine sentiments the instruments for the destruction of all values of a free civilization" (II: xii), leading to "the destruction of the indispensable environment in which the traditional moral values alone can flourish, namely personal freedom" (II: 67, also 62). The phrase had become a source of "sloppy thinking and even intellectual dishonesty" (II: 80), a "dishonest insinuation... intellectually disreputable, the mark of demagogy and cheap journalism which responsible thinkers ought to be ashamed to use because, once its vacuity is recognized, its use is dishonest" (II: 97). ${ }^{8}$ In his later work on the errors of socialism, entitled The Fatal Conceit, he called the word "social" a "weasel word" confusingly use to qualify over 160 nouns, from social accounting to social work. Hayek referred to "social justice" as "much the worst use of 'social', one that "wholly destroys" the meaning of the word it qualifies, a "semantic fraud." Hayek even noted with alarm that the term had "already perverted the thinking of a younger generation," citing David Miller's recent Oxford doctoral thesis, entitled "Social Justice."9

Given all of this, one is naturally surprised to read Hayek saying that the differences between himself and John Rawls are "more verbal than substantial" (II: xiii), and that Rawls and Hayek agree on "the essential point," which is that principles of justice apply to the rules of institutions and social practices, but not to distributions of particular things across specific persons (II: xiii, 100). After all, Rawls did use the term "social justice." Indeed, Rawls qualified a large range of things as being "of social justice," including principles and

$7 \quad$ Hayek, Social Justice, Socialism and Democracy, 3.

8 See also Hayek, Social Justice, Socialism and Democracy, 3.

9 F.A. Hayek, The Fatal Conceit: Errors of Socialism (Routledge, 1988), 114-18. 
standards $(4,5,7,47,290)$; conceptions and theories $(8,9,10,16,21,85,92,100,135,285)$;

convictions and considered judgments (18, 34); purposes and ends (179, 188); matters, concerns, and standard cases $(50,76,92)$; questions and problems $(39,78,92,118,132,135$, $136,174,479)$; and the standpoint of social justice $(40,49,91)$. Rawls said that principles of justice "define the appropriate distribution of the benefits and burdens of social cooperation." 10 The phrase "distributive justice" was of course also the target of Hayek's ire. ${ }^{11}$ Hayek claimed that people had misread Rawls, ignoring his point that if a distribution results from just institutions it is just no matter what it is. Yet it clearly seems that for Rawls, justice in institutions was itself defined at least partly in distributive terms. If one thinks of the familiar contrast between old, or classical liberalism and new, or social justice liberalism $^{12}$, Rawls is clearly a social justice liberal. So how could Hayek have claimed to be in agreement with Rawls? This is the historical and interpretive puzzle I want to address in my lecture tonight.

The odd proximity of Hayek and Rawls has been noted in the past. From the left, the argument has been made that if Hayek can agree with Rawls, there's something wrong with Rawls. ${ }^{13}$ From the right, Ayn Rand referred to Hayek's views as "poison." ${ }^{14}$ In the middle, some hold out hope for a "Rawlsekian" synthesis. ${ }^{15}$ The intellectual prospects for such a

10 John Rawls, A Theory of Justice (Cambridge, Mass.: Harvard Univeristy Press, 1999), 4, 6, 8. Henceforward all references to Theory will be made parenthetically in the text, to this, the revised edition. Hayek would of course have read the original edition. However, the many small differences and some larger differences between the two works do not affect any of the points at issue between Hayek and Rawls.

11 C.f. II: Chapter Nine, which is entitled "Social or Distributive Justice," as well as 137 and elsewhere. See also Hayek, Social Justice, Socialism and Democracy, 4; Hayek, The Fatal Conceit, 118.

12 Gerald F. Gaus, "On Justifying the Moral Rights of the Moderns: A Case of Old Wine in New Bottles," Social Philosophy and Policy 24, no. 1 (2007), 84.

13 Lawrence J. Connin, "On Diquattro, "Rawls and Left Criticism"," 13, no. 1 (1985): 138-41.

14 "As an example of our most pernicious enemy, I would name Hayek. That one is real poison;" letter to Rose Wilder Lane, 1946, cited in Roderick T. Long, "Praxeology: Who Needs it," The Journal of Ayn Rand Studies 6, no. 2 (2005), 312.

15 Brink Lindsey, "Liberaltarians," http://www.cato.org/pub_display.php?pub_id=6800 (accessed May 13, 2011); Will Wilkinson, "Is Rawlsekianism the Future?," http://www.cato-at-liberty.org/is-rawlsekianismthe-future/ (accessed May 13, 2011); Will Wilkinson, "The Rawls in Rawlsekianism," 
synthesis are quite good, I think, because at the level of normative principle, Hayek is in many ways a Rawlsian. I will outline four main areas of convergence: the importance of 'pure procedural justice', the irrelevance of merit, the use of a veil of ignorance, and the principle the inequalities should benefit everyone. Hayek manages manages to avoid reaching egalitarian conclusions by making implausible slippery slope arguments about the lack of politically stable intermediate possibilities, between a minimal, nightwatchman state and the totalitarian order that would be necessary to achieve perfect equality, and by equivocating about the meaning of central normative concepts and principles. ${ }^{16}$

To some extent, my discussion of Hayek today will simply rehearse what I regard as the decisive objections to his critique of social justice that have made by others. Lack of originality will not detract from the importance of the claims I want to make, in these days of conservative ascendency, nor their usefulness, I hope, to those of you who are not fully up to speed on your Hayek. If Hayek is right about social justice, there ought not be such a thing as a Center for the Study of Social Justice, as there is here at Oxford, and Balliol ought not be churning out graduates labouring under the delusion that they live in societies that lack something they couldn't possibly have. If Hayek is wrong about social justice - if Hayek actually believes in social justice, at some deep level, but refuses to admit it - then conservatives in London or Ottawa who look to Hayek to provide principled support for their free-market fundamentalism are looking in the wrong place.

http://www.willwilkinson.net/flybottle/2008/04/08/the-rawls-in-rawlsekianism/ (accessed May 13, 2011). Also in this vein, I think, is Claude Gamel, "Hayek Et Rawls Sur La Jusice Sociale: Les Différences Sont-Elles Plus Verbales Que Substantielles?," Cahiers d'economie politique 54 (2008): 85-120., although Gamel's purposes are primarily analytical rather than ideological.

16 There is thus a substantial degree of truth in the claim that Hayek and Rawls disagree about empirical questions about politics and economics, rather than about philosophical principles; Don Arthur, "Hayek \& Rawls: An Unlikely Fusion," http://evatt.labor.net.au/publications/papers/191.html (accessed May 8, 2011). I would only insist that the agreement on principles makes Hayek a Rawlsian, rather than making Rawls a Hayekian. That is to say, when one presses Hayek for a consistent articulation of his principles, one finds a form of egalitarian liberalism, which generates right-wing conclusions only given implausible empirical 


\section{The Irrelevance of Hayek's Conceptual Claims}

So what is Hayek's argument against social justice? ${ }^{17}$ Appearances to the contrary, he

is not really claiming that the idea of social or distributive justice is meaningless. Hayek

starts by arguing that "only human conduct can be called just or unjust," and that when applied to a state of affairs, these terms have meaning "only in so far as we hold someone responsible for bringing it about or allowing it to come about" (II; 31). ${ }^{18}$ He thus allows that states of affairs e.g. distributions can be just or unjust in a derivative sense, if we hold someone responsible for causing the state of affairs or allowing it to persist. He then moves to the stronger claim that "only situations created by human will can be called just or unjust," with the result that "if it is not the intended or foreseen result of somebody's actions that A should have much and B little, this cannot be called just or unjust;" (II, 33). As others have noted, there seems to be a leap of logic here. If someone did have a duty to prevent or rectify B's poverty or the inequality between A and B, which Hayek's opening claim allows, then the inequality would be unjust, despite not having been intentionally brought about. Hayek does not deny that we may have a moral duty to alleviate suffering caused by others or by nature. ${ }^{19}$

assumptions, as well as some equivocation about key terms.

17 Steven Lukes has distinguished 6 different claims that Hayek makes, in his chapter on social justice, including the claims that social justice is meaningless, religious, self-contradictory, and ideological, as well as the claims that a socially just market order is infeasible and disastrous; Lukes, "Social Justice: The Hayekian Challenge," 67-71. While it is useful to draw these distinctions, a fair assessment of Hayek's view depends upon sympathetically reconstructing the structure of his argument, which I think is not best captured as a list of six theses. To some extent, the same criticism applies to Adam James Tebble's distinction between what he sees as Hayek's four critiques of social justice, based respectively on meaningfulness, atavism, feasibility, and compatibility with a market order; Adam James Tebble, "Hayek and Social Justice: A Critique," Critical Review of International Social and Political Philosophy 12, no. 4 (2009), 582-90.

18 Consequentialists would argue that just conduct can only be defined in terms of the just states of affairs it must bring about; see, for example, David Miller, Social Justice (Oxford University Press, 1976), 17; Alistair Macleod, "Justice and the Market," Canadian Journal of Philosophy 13, no. 4 (1983), 557. Even if one is not a consequentialist, however (i.e. even if one accepts some moral rights as side constraints, and so accepts that just conduct is not always a matter of behaving in whatever way will maximize just states of affairs), one might still believe that among the duties we have is a duty to help prevent or to remedy particular distributive outcomes. 19 "A state of affairs that no one has intended or foreseen may, nevertheless, require action to alleviate 
And for all Hayek has said, it might be that we also have duties to help reduce inequality caused by others or by nature, or to share fairly in the benefits of cooperation. Principled libertarians might deny that individuals can rightly be forced to aid each other or share fairly in the benefits of cooperation, but Hayek does not make that argument; in fact, we will later see that he implicitly rejects it by accepting the legitimacy of state provision of income support for those who can't support themselves in the market. Moreover, there is the question of how we design or reform the rules within which individuals interact, which can have important distributive consequences. There are different ways of delimiting rights of property and contract, and different ways of framing the market with public institutions, many of them consistent with protecting people's basic liberties and preserving the virtues of the market that Hayek champions, but some that raise the prospects of the lowest position more than others. Such decisions would seem to count as collective conduct that could be just or unjust, if there were any duties of distributive justice. ${ }^{20}$

So Hayek's fundamental claim is not conceptual. His real argument is that social or distributive justice is impossible within the "spontaneous order" of a "great society" or "open society," i.e. a market society, ${ }^{21}$ and that we have decisive reasons for preferring market society. Ultimately, then, his claim is that social justice is trumped by other values; the

suffering or deprivation, and failure to take such action may be justly condemned as unjust;" Lukes, "Social Justice: The Hayekian Challenge," 72. See also Raymond Plant, Modern Political Thought (Wiley-Blackwell, 1991), 92-93; Tebble, "Hayek and Social Justice: A Critique," 591.

20 This a point that others have made in response to Hayek. David Miller notes that "it is possible to study the distributive outcomes of a market and to consider how a change in the ground rules might alter these outcomes." Miller offers the example of laws against discrimination by sex or race in the labour market, which do not abolish the market but merely change its ground rules. "Essentially the same process occurs when the respective rights of landlords and tenants are change, when consumer protection legislation is introduced, when cartels to fix prices are made illegal, and so forth;" David Miller, Principles of Social Justice (Harvard University Press, 1999), 108-09. David Johnston also discusses the more or less predictable distributive consequences of legislative decisions about how to design and frame the market; David Johnston, "Is the Idea of Social Justice Meaningful?,” Critical Review 11, no. 4 (1997), 610.

21 Thus, Hayek says that it is misleading to call states of affairs just or unjust "in the case of a spontaneous order," where "the resulting state was not the intended aim of the individual actions... [W] hat is called 'social' or 'distributive' justice is indeed meaningless within a spontaneous order and has meaning only 
crucial issue will be to figure out exactly what he means by social or distributive justice.

\section{The Spontaneous Order of a Great Society}

To answer this question, we need to know what form of justice is incompatible with a "spontaneous order." Hayek's idea of spontaneity refers both to the origin of the rules that first give rise to order, and to the character of an order even after the rules have been modified by intentional acts of legislation. Human societies are normative or rule-governed arrangements that were initially the product of evolution rather than conscious design. We didn't start out as the individually rational consequentialists of economic theory, but as herd animals that very slowly developed complicated social norms and eventually explicit rules. Human societies were subject to selection pressures. If a particular rule tended to disrupt group life, or weaken the group in competition with others, that rule would tend to be weeded out of the population of human societies. If a particular rule promoted cohesion and strength, it would tend to be selected. Over the course of millennia, systems of social rules could evolve that were far more complicated and based on far more information than any single agent with limited knowledge and cognitive capacities could ever have designed. ${ }^{22}$

By itself, the idea of a social order originating in evolution rather than conscious design doesn't get us very far towards the rejection of social justice. At best, it gives us reason for exercising caution in revising the rules of existing social practices, since they may contain an evolutionary wisdom that is not immediately apparent to our bounded rationality. However, there is no particular reason to think that evolution aims at justice. Success in inter-group competition might be achieved via the adoption of very unpleasant norms. 
Slavery seems to have been common, historically.

Hayek is not primarily concerned with the spontaneous origin of rules, however, but with the spontaneous character of order in a system of general rules allowing individuals scope to pursue their own purposes. The order resulting from interaction within a set of rules can be spontaneous in the sense of not being the goal that any agent intended to bring about even if via legislative revision all of the rules are now made rules rather than spontaneous rules (I: 46). What is crucial is that the rules be general rules for whole classes of individuals, not specific individuals by name or highly specific designation (I: 50), and that the rules not aim at any general purpose except for that of ensuring that individuals treat each other justly, by which Hayek means primarily that they respect a range of negative rights, e.g. the right not to be assaulted or killed, the right not to have their property taken. These negatives rights establish a set of protected individual domains (II: 37-38, 103). Such rules allow the individual to pursue her own distinctive aims according to the specific information available to her, within the context of rules that allow others to do likewise, which is one of Hayek's definitions of freedom (I: 55). ${ }^{23}$ When social rules have this abstract character, the specific patterns that interaction gives rise to will depend upon a whole range of facts that the designers of specific rules could not possibly have known, facts known only to particular persons in particular situations, making the order spontaneous in relation to the intentions both of those who made the rules and those who interact within them. ${ }^{24}$ The resulting order is spontaneous even if legislation has obscured the evolutionary origin of the rules that give rise

interpret legislative acts but articulated, specified and attempted to render consistent pre-existing social rules that no one ever consciously invented (I: 72-123).

23 See also Hayek, Social Justice, Socialism and Democracy, 4.

24 "The particular content of the order will depend on the concrete circumstances known only to the individuals who obey the rules and apply them to the facts known to them. It will be through the knowledge of these individuals both of the rules and of the particular facts that both will determine the resulting order;" (II; 46). 
to this order.

By this point we are very close to the Great or Open society, but to get all the way there we need to add one background fact and one institution: moral disagreement, and the market, which is a specific instance of a system of abstract rules. In a large, modern society, people will have a great many different ends, both personal and ideological (religious, ethical, philosophical, and so on). Using the market to make social decisions about how to allocate resources avoids a whole range of potentially very difficult, disruptive questions on which the various ideals present in society would otherwise clash (II:, 3-4, 109-110). The great discovery of market society is not how selfishness can be turned to serve the public interest, but how people with radically different ends can be led to cooperate, each acting for his or her own purposes, but in a way that is generally beneficial for others. ${ }^{25}$

We are now in a position to understand Hayek's claim that social justice is incompatible with the spontaneous order of a Great Society, as well as an initial point of similarity with Rawls.

\footnotetext{
"In a spontaneous order the position of each individual is the resultant of the actions of many other individuals, and nobody has the responsibility or the power to assure that these separate actions of many will produce a particular result for a certain person... There can, in a spontaneous order, be no rules which will determine what anyone's position ought to be. Rules of individual conduct... determine only certain abstract properties of the resulting order, but not its particular, concrete content (II: 33; emphasis added).
}

The distribution of wealth, say, across specific individuals Alf, Betty, and Charlie, cannot be guaranteed by any general rules of just conduct. It could perhaps be guaranteed if society

\footnotetext{
25 "In the Great Society we all in fact contribute not only to the satisfaction of needs of which we do not know, but sometimes even to the achievement of ends of which we would disapprove if we knew about them. We cannot help this because we do not know for what purposes the goods or services which we supply to others will be used by them. That we assist in the realization of other people's aims without sharing them or even knowing them, and solely in order to achieve our own aims, is the source of strength of the Great Society. So long as collaboration presupposes common purposes, people with different aims are necessarily enemies who may fight each other for the same means; only the introduction of barter made it possible for the different individuals to be of use to one another without agreeing on ultimate ends;" (II: 109-110). This insight has been emphasized recently by Gerald Gaus, in his "jurisdictional" account of property rights, which draws on Hayek indirectly by way of John Gray; Gerald F. Gaus, The Order of Public Reason: A Theory of Freedom and
} 
were set up like an organization, in which rules are subordinate to commands with specific objectives, but then we would have sacrificed freedom, innovation, and prosperity.

The point I want to insist upon is that Hayek's critique of social or distributive justice has a very narrow target. His claim is that in the spontaneous order of a market society it is impossible to ensure distribution according to any individualistic pattern of merit or deservingness. ${ }^{26}$ Hayek stresses that in a market system prices are signals about the relative scarcity of resources in relation to people's preferences over the uses to which different resources might be put. Prices provide indications about how people ought to behave, not rewards for how they have behaved in the past. The rewards people obtain in a market economy cannot correspond in any strict way to individual merit. The market is a game of skill and chance - and people's skill is partly a matter of genetic chance, Hayek would have had to admit. The market must reward luck as well as conscientious effort, if it is to serve its function of aggregating information about relative scarcity of resources in relation to preferences over uses. What matters to prices in a market is scarcity now, not conscientious effort in the past, except to the extent that effort is correlated with production of things other people find they want (II: 80-81). If the economic system is to take advantage of all the dispersed knowledge in the population, and explore all possibilities of production in order to discover facts as of yet unknown, we must accept that "success is based on results, not on motivation." 27 Someone may work hard and skillfully at a given project given the best knowledge available at the time, only to discover that by the time it is complete people's

Morality in a Diverse and Bounded World (Cambridge: Cambridge University Press, 2010), 374-75.

26 Others have noticed that Hayek is only claiming that "social justice" is meaningless in the context of a Great Society; Eric Mack, "Hayek on Justice and the Market: A Reply to Macleod," Canadian Journal of Philosophy 13, no. 4 (1983), 571-72; Lukes, "Social Justice: The Hayekian Challenge," 68. What I emphasizing, however, is that Hayek's claim really only applies to a certain kind of principle of social justice, namely, principles based on considerations of individual merit.

27 Hayek, The Fatal Conceit, 118. Hayek is quote Alchian 1950 - check. 
preferences have changed in an unpredictable way, or that someone else has by accident (perhaps without even much effort) discovered a new way of doing things. The results of the market will therefore often seem unfair, just as nature seems unfair in visiting calamity upon the deserving, and good fortune upon the undeserving (II: 68-9). The divergence of the distribution of income and wealth from the distribution of individual merit is the result of allowing individuals the freedom to choose their own occupation, their own level of work and leisure, their own package of consumption, and generally to use the particular knowledge they have as they see fit in view of their own goals. ${ }^{28}$

The obvious problem with Hayek's argument is that distribution according to merit is just one conception of social justice. Consider the principles of fair equality of opportunity, and raising the lowest social position as much as possible. Since neither of these principles requires distribution according to individual merit, neither falls afoul of Hayek's objection.

Hayek comes close to admitting as much at the end of his critique, when he briefly addresses Rawls's Theory of Justice.

[T]he recognition that in such combinations as 'social', 'economic', 'distributive' or 'retributive' justice the term 'justice' is wholly empty should not lead us to throw the baby out with the bath water... [T] here unquestionably... exists a genuine problem of justice in connection with the deliberate design of political institutions, the problem to which Professor John Rawls has recently devoted an important book. The fact which I regret and regard as confusing is merely that in this connection he employs the term 'social justice' (II: 100)

I don't think Hayek has thrown out much bathwater. True, he talks of "political" rather than "social" institutions, but Hayek has to admit that there are different ways of designing the rules of property and contract, and he has as of yet provided no reason for thinking that the

28 The narrowness of Hayek's critique is absolutely clear in his later attack on the errors of socialism. He remarks that "social justice" has come to mean "distributive justice," but that distributive justice is "irreconcilable with a competitive market order." He recognizes that people might be happier if the "relative economic positions of individuals" were just. "Yet the whole idea behind distributive justice - that each individual ought to receive what he morally deserves - is meaningless in the extended order of human cooperation; "Hayek, The Fatal Conceit, 118. The reason he offers for this conclusion is that the size of the "available product" depends on "what is in one way a morally indifferent means of allocating its parts." The moral indifference he's referring to is the necessity that markets should capitalize on luck in order to synthesize 
distributive effects of such decisions cannot be judged just or unjust. Moreover, he admits that "there is no reason why in a free society government should not assure to all protection against severe deprivation in the form of an assured minimum income." He even admits that such a scheme "may be felt to be a clear moral duty of all to assist... those who cannot assist themselves," rather than simply a prudent form of social insurance (II: 87$).{ }^{29}$ So long as this minimum is provided outside the market without any other interference with the price mechanism, Hayek says, there is no threat to freedom or the rule of law. The problems he is concerned with, he says, are those that arise when the levels of remuneration for different services are set by authority rather than by the market (paraphrasing II: 87). Hayek provides no reason for thinking that income support or public support of education is not a requirement of social justice, e.g. equal opportunity. His strictures against schemes designed to achieve social justice only apply to attempts to make the distribution of income correspond to individual merit, which would interfere with the setting of market prices. ${ }^{30}$

dispersed information and explore all possibilities of production.

29 "Hayek concedes that people may have obligations to help each other even when those so obliged did not cause the distress to be alleviated-indeed, when this distress is the result of an impersonal, spontaneous order;" Lukes, "Social Justice: The Hayekian Challenge," 73. Don Arthur notes that unlike Ludwig von Mises, Hayek consistently supported government provision of a minimum income and public subsidy of education, and was for this reason criticized by libertarians such as Ayn Rand; Don Arthur, "Hayek \& Rawls: An Unlikely Fusion." Tebble along with other critics suggests that Hayek's admission that government can provide a minimum income is incompatible with Hayek's earlier claim that distributive justice is infeasible, since a public minimum will lead to there being less inequality than there would otherwise have been; Tebble, "Hayek and Social Justice: A Critique," 597-8, 601. In contrast, I think that Hayek's support for some form of income support outside the market simply shows that he was only rejecting a very specific kind of distributive justice, i.e. individual merit-based principles.

30 C. f. Lukes, "Social Justice: The Hayekian Challenge," 73-74. Elizabeth Anderson also remarks on the narrowness of Hayek's result. What Hayek saw, according to Anderson, was that distributive principles based on assessments of individual merit were incompatible with any social order involving a substantial degree of individual freedom. "What would a society be like if it tried to distribute goods according to some notion of individual merit or desert? Given that the outcomes of free exchanges inveitably include some element of chance, to adjust the outcomes so that they reflect some prior notion of merit or desert would require that the state look over everyone's shoulders to see how they are using their liberties. If, in the state's judgment, an individual used her liberties poorly or irresponsibly, then she is responsible for whatever disadvantages come her way and society will not compensate her for them. But if the state judges that her disadvantages were the result of mere luck, which is undeserved, then society will compensate her. There are of course other ways to draw the line between deserved and undeserved outcomes... But all of the ways of drawing the line and redistributing goods accordingly require the state to make and enforce intrusive judgments about how people are 
In his earlier work, The Constitution of Liberty, Hayek did make an argument against redistribution in general, even where not the underlying distributive principle is not meritbased $^{31}$, an argument based on the moral constraints on coercion. This argument is clearly unsuccessful, however. Hayek conceded that a more equal distribution of income or wealth was desirable, but pointed out that desirability was not a sufficient justification for coercion. The basic postulate of a free society, Hayek argued, was "the limitation of all coercion by equal law." It was therefore illegitimate to resort to "discriminatory coercion or privilege" in the goal of remedying economic inequality. ${ }^{32}$ Hayek also conceded, however, that if there was a legitimate need for state action to achieve some legitimate objective (other than reducing inequality) but different ways of achieving the objective, "those that incidentally also reduce inequality may well be preferable;" he gives the example of different ways of designing the law of intestate succession. ${ }^{33}$ This concession seems fatal, since the laws of property and contract are enforced by state coercion, and there are more or less egalitarian ways of designing systems of property rights (e.g. is inheritance of wealth permitted?).

Hayek could respond by denying that enforcement of property rights is coercive, and given the way he defined liberty and coercion, there is some validity in this objection, although it opens Hayek up to an equally difficult problem. Hayek objected very strenuously

using their freedom. People can't be free under such a system, where the state is monitoring their choices and passing moral judgment on them, with attendant material consequences. This is the ultimate busybody state" Elizabeth Anderson, "So You Want to Live in a Free Society (1): What Hayek Saw," http://left2right.typepad.com/main/2005/05/so_you_want_to_.html (accessed May 8, 2011). See also Don Arthur: "For Hayek, 'social justice' meant allocative justice - the demand "for an assignment of the shares in the material wealth to the different people and groups according to their needs or merits" (Hayek, 1991: 121);" Don Arthur, "Hayek \& Rawls: An Unlikely Fusion."

31 In this work, Hayek distinguished patterns of distribution in general (e.g. more or else equal) from distribution according to individual merit. "Our objection is against all attempts to impress upon society a deliberately chosen pattern of distribution, whether it be an order of equality or inequality. We shall indeed see that many of those who demand an extension of equality do not really demand equality but a distribution that conforms more closely to human conceptions of individual merit and that their desires are as irreconcilable with freedom as the more strictly egalitarian demands;" Friedrich A. von Hayek, The Constitution of Liberty (London: Routledge and Kegan Paul, 1960), 87.

32 Hayek, The Constitution of Liberty, 87-88. 
to confusing liberty with power or the absence of impediments to what one might want to do, because liberty as power or capacity lent itself to socialist attempts to turn "freedom from want" against individual liberty. ${ }^{34} \mathrm{He}$ insisted that freedom was a relations between persons. Hayek defined liberty in quasi-republican fashion as absence of dependence on the arbitrary will of another. ${ }^{35}$ In the same vein, he defined "coercion" as control of a person's environment or circumstances such that "he is forced to act not according to a coherent plan of his own but to serve the ends of another," and so "unable to use either his own intelligence or knowledge or to follow his own aims." ${ }^{36}$ The republican tradition of liberty as nondomination is a strictly interpersonal conception that classifies Robinson Crusoe as free. Yet it can easily be harnessed to argue for more equal distributive outcomes precisely on the grounds of protecting individuals from being subject to the arbitrary will of others. Hayek recognized that threat of state coercion was necessary to prevent coercion, but insisted that the worst effects of such coercion could be reduced to a minimum by operating only through known general rules whose effect on particular individuals cannot be foreseen at the time the rules are made. Because liberty means not being subject to someone else's will, having a framework of known general rules does not make individuals subject to the arbitrary will of those who made the rules, but permits people to plan their own lives in view of their own ends. Hence state enforcement of property rights does not make individuals subject to its will. Nonetheless it is clear that if resources are privately owned and society makes no

33 Hayek, The Constitution of Liberty, 88.

34 C.f. Hayek's disparaging remarks about Roosevelt's four freedoms; Friedrich A. von Hayek, The Mirage of Social Justice (Chicago: University of Chicago Press, 1976), 101-06.

35 Hayek, The Constitution of Liberty, 87-8@12-13. But see Gamel, "Hayek Et Rawls Sur La Jusice Sociale: Les Différences Sont-Elles Plus Verbales Que Substantielles?", 115., who argues that Hayek has a negative conception of liberty. Gamel claims that if Hayek is to be true to his conception of liberty as the absence of coercion, he ought not support state provision of a minimum income, and that if he believes such a policy is legitimate, he must endorse a more positive conception of liberty. In contrast, I take Hayek's conceptions of liberty and coercion to be fundamentally republican in character, making his support for state provision of a minimum income consistent. 
provision to ensure access to employment, education, and so on, those without property will tend to be subject to the will of those with property. The only way Hayek avoids legitimizing measures to reduce economic inequality in the interests of non-domination is by watering down the notion of coercion, and by making demanding empirical assumptions about the level of coercion in a market society. It is only in very exceptional circumstances that control of a resource or a service allows one person to dominate another, he claims. A monopolist of an essential good may be able to coerce, but the individual provider of employment cannot normally exercise true coercion, because employees can leave and find work elsewhere. Periods of acute unemployment would, Hayek claims, be "rare exceptions in a prosperous competitive economy." ${ }^{37}$ Perhaps. But there is no general argument here against state action in view of distributive goals.

\section{Pure Procedural Justice and the Irrelevance of Merit}

We've seen that Hayek's critique of social justice is really a critique of distribution according to individual merit, assuming that society must be a scheme of cooperation governed by general rules that allow broad scope for individual liberty. His sympathy for Rawls is therefore readily intelligible, given Rawls's commitment to pure procedural justice and his denial that desert is a fundamental principle of justice. Rawls too argued that principles of justice applied to institutional rules rather than distributions directly. ${ }^{38}$ The basic

\footnotetext{
36 Hayek, The Constitution of Liberty, 21.
}

37 Hayek, The Constitution of Liberty, 136.

38 Hayek picks out a 1963 statement of this point, and comments that he cannot find a comparably clear statement of this point in A Theory of Justice, which (he says) may be why people have wrongly interpreted Rawls major work as a defence of a socialistic ethic. Here, Hayek cites a 1972 article by Daniel Bell. Bell noted that Rawls claims that the distribution of natural talents is morally arbitrary, that he denies that a just society would be subject to the objection that it is meritocratic, and that he treats talents as a common asset, and concluded that Rawls was committed to equality of result rather than equality of opportunity. Bell said that Rawls provided the rationale for a fundamental shift in values; instead of "from each according to his ability, to each according to his ability" a Rawlsian society would satisfy the socialistic ethic "from each according to his ability, to each according to his need;" Daniel Bell, "On Meritocracy and Equality," The Public Interest 29 (1972), 37. It is conceivable that Rawls's views changed between 63 and 71, which would explain why Hayek 
structure of society is a public system of rules, for example rules about property and contract.

Distributions across individuals arise because people make choices within these rules, choosing in light of the options the rules make available. Were the rules different, they would choose differently, and a different distribution would result. ${ }^{39}$ If we have a just set of rules, the distribution that results from voluntary interaction within these rules is just no matter what it is. Distributive justice thus involves an element of pure procedural justice. The rules are not a means to bringing about a particular result, as in the case of more or less perfect procedural justice (splitting a cake by the "you cut, I choose" rule, or a criminal trial). Distributive justice is more like gambling; if the bet was freely entered under fair conditions, the result is fair no matter what it is. One cannot take a stock of goods distributed across particular individuals and judge it to be just or unjust independent of the institutional system from which it resulted, by way of choices and agreements made in good faith within this system (paraphrasing 76).

The obvious problem with Rawls's use of pure procedural justice is that although principles of justice apply first to institutional rules, not distributions, he defines just institutions at least in part in terms of distributions, e.g. fair equality of opportunity and raising the position of the worst off. So aren't judgments about distributions primary after all? $?^{40}$ The answer is 'yes,' but we're no longer talking about distributions across particular

couldn't find a clear statement of the view that principles of justice apply to institutional rules, not to distributions independent of their causal origins. But in fact Rawls did say much the same thing, under the heading of "pure procedural justice."

39 "What a person does depends upon what rules say he will be entitled to [depending how he acts], and what a person is entitled to depends on how he acts. The distribution which results is arrived at by honouring the claims determined by what persons undertake to do in light of these legitimate expectations" (74).

40 Thus David Miller is led to deny whether Rawls's principles "represent a pure procedural conception of justice." Both the principle of fair equality of opportunity and the difference principle prescribe a particular distributive outcome. "Had Rawls wished to make his account pure procedural, he should have omitted the two principles and prescribed only the institutional framework; for instance, if one maintained that whatever distribution resulted from the workings of a free market economy was fair, this would be a pure procedural interpretation of justice;" Miller, Social Justice, 44-45. Miller goes on to deny that our ordinary notions of 
individuals. Rather, we're talking about distributions across social positions. We choose systems of institutional rules based on the distribution of positions they make available, then individuals interact within these rules, and the resulting distribution across individuals is just no matter what it is.

The rationale for focusing on social positions is that people will be born into different starting points in life, which make it more or less likely that they will be able to succeed. People are born with different levels of innate talent. And assuming that liberty must permit private childrearing in some form, we will never have perfect equality of opportunity. Moreover, even if there were perfectly fair equality of opportunity and no differences in levels of innate talent, any economic system involving the market will involve a substantial element of luck. People who are willing to work and play by the rules will suffer unmerited failure; others less meritorious will win success.

[T] he extent of one's contribution (estimated by one's marginal productivity) depends upon supply and demand. Surely a person's moral worth does not vary according to how many offer similar skills, or happen to want what he can produce. No one supposes that when someone's abilities are less in demand or have deteriorated (as in the case of singers) his moral deservingness undergoes a similar shift. All of this is perfectly obvious and has long been agreed to (274).

Since everyone depends on the cooperation of others, we ought not take advantage of this morally arbitrary luck to claim a greater share of what we produce together - not unless this inequality will make everyone better off. We ought to assess the design of economic institutions from the perspective of the lowest position. This doesn't mean that we have to maximize the income of the least responsible individual - someone who is unwilling to work or follow the laws, say. Rather, we should assess economic institutions from the point of view of someone willing to work and follow the rules, but who happens to have been born without a lot of innate talents, at least not ones currently in demand, and born into a family at justice are purely procedural; "rather, institutions are assessed in terms of independent criteria of distributive 
the bottom end of the distribution of income and wealth.

Rawls's principles thus have a hybrid character, in relation to pure procedural justice.

Distributions across individuals are just so long as they resulted from interaction within just institutions, but just institutions are defined in part in terms of their tendency to produce the right distributions across social positions. Appreciating this hybrid character is essential to understanding how Rawls's principles avoid two prominent criticisms. The first is the Nozickean claim that liberty upsets patterns; the second is Will Kymlicka's Dworkinian criticism that the difference principle is not sufficiently sensitive to ambition.

Nozick's argument goes like this: assume a just distribution, whatever one thinks that is, and then let individuals engage in fully informed and voluntary exchange. The resulting distribution will no longer fit whatever distributive criterion we specified, and to get back to the right pattern the state will have to take away what individuals acquired without injustice and give it to others, which doesn't seem fair. ${ }^{41}$

The ambition critique is structurally similar. Start with an equal distribution of land between two equally talented gardeners, Ian the industrious, and Christine the contemplative. $^{42}$ Next, individuals make fully informed and voluntary decisions about work, leisure, and consumption. For example, Ian works hard in the garden so that he can afford to buy a big TV, while Christine only works a little, because she takes pleasure in walking in the woods. As a result, there is inequality between Ian and Christine. By the difference principle, this inequality is only permitted if it benefits the least well off person - Christine. To ensure that justice is preserved, government may have to take some money away from Ian and give it Christine. But that doesn't seem fair.

justice, such as desert and need. The situation is one of imperfect procedural justice."

41 Robert Nozick, Anarchy, State, and Utopia (New York: Basic Books, 1974), 160.

42 Will Kymlicka, Contemporary Political Philosophy : An Introduction (Oxford: Clarendon Press, 
The mistake in both these cases is that principles of justice apply to institutional rules, not to distributions across specific individuals. If individuals engage in voluntary transactions within the framework of just rules, the resulting distribution is just no matter what it is, even if that involves Lionel Messi having more money than me, for example. But just rules are defined partly in terms of ensuring that there is fair equality of opportunity and raising the lowest social position. If a progressive income tax is necessary to achieve these goals, then distributions of rights over resources would only be just to the extent that they are compatible with such taxation. There is no just distribution of resources that does not allow for institutions necessary to maintain FEO and the DP, i.e no just distribution of absolute property rights. $^{43}$

Now take the gardener case. If the rules defining property, contract, inheritance, etc. are just, then whatever distribution between Ian and Christine results from their decisions is just no matter what it is; this is the idea of pure procedural justice. But these rules will not be just unless they protect people's basic liberties, secure them fair equality of opportunity, and permit inequalities only if they raise the lowest social position. If the rules defining property etc. are not just, then the distribution between Ian and Christine will not be just, but not because of the extra inequality between them due to their decisions. Rather, the problem is the extra inequality between the broad social positions due to the design of the institutions. ${ }^{44}$

1990), 72-75.

43 This critique of Nozick's argument about liberty and patterns is originally due to Cheyney Ryan and G. A. Cohen; Cheyney Ryan, "Yous, Mine, and Ours: Property Rights and Individual Liberty," Ethics 87, no. 2 (1977): 126-41; G. A. Cohen, Self-Ownership, Freedom, and Equality (Cambridge: Cambridge University Press, 1995). Cohen's Wilt Chamberlain paper was first published in 1977. Will Kymlicka and Jonathan Wolff provide good accounts of the argument; Kymlicka, Contemporary Political Philosophy, 102-27; Jonathan Wolff, Robert Nozick: Property, Justice and the Minimal State (Key Contemporary Thinkers) (Polity Press, 1991), 73-118.

$44 \quad$ Philippe Van Parjis has argued that when understood to apply across social positions, the difference principle is "far more responsibility-friendly (or ambition-sensitive) and hence less egalitarian (in outcome terms) than is generally understood;" Van Parijs, "Difference Principles," in The Cambridge Companion to Rawls (Cambridge: Cambridge University Press, 2003), 216. The point I am emphasizing is that there is a 


\section{Inequalities Should Benefit Everyone}

Having ruled out distribution according to merit, what principles should we use to

design social institutions?

One might claim that it is a mistake from Hayek's point of view to talk of designing institutions, an example of what he called the constructivist fallacy. Constructivists wrongly assume that order results from the intention of a designing agent, e.g. a ruler, and neglect the fact that evolved order can be more complex and better adapted than made orders (I: 8-35). The crucial word here is "can". Hayek never claims that social evolution is always optimal. He admits that it can lead down blind alleys, that grown rules may need to be reformed by legislation (I: 88-89). This is one reason he denied being a conservative. ${ }^{45}$

Hayek offers a method for assessing social institutions, one that is strikingly Rawlsian.

[W]e should regard as the most desirable order of society [note that he doesn't say most just, but he hasn't provided any reason for thinking that we can't use this term in this context] one which we would choose if we knew that our initial position in it would be decided purely by chance (such as the fact of being born into a particular society). Since the attraction such chance would possess for any particular adult individual would probably be dependent on the particular skills, capacities and tastes he has already acquired, a better way of putting this would be to say that the best society would be that in which we would prefer to place our children if we knew that their position in it would be determined by lot. (II: 132)

Uncertainty about social position combined with some uncertainty about genetic potential and about specific tastes and interests closely resembles Rawls's veil of ignorance. ${ }^{46}$

structural similarity between the Nozickian and Dworkinian critiques of the difference principle, and that position-based / pure-procedural-justice response to the Dworkinian objection about responsibility and ambition is the same as the Ryan / Cohen response to Nozick's objection about liberty and patterns.

$45 \quad$ Hayek, The Constitution of Liberty, 397.

46 As others have noted; Arthur M. Diamond, "F. A. Hayek on Constructivism," The Journal of Libertarian Studies 4, no. 4 (1980), 362-63; John Gray, "Hayek and Classical Liberalism: A Bibliographical Essay," Literature of Liberty: A Review of Contemporary Liberal Thought, http://oll.libertyfund.org/?option=com_content\&task=view\&id=171\&Itemid=280\#_ftnref73 (accessed May 8, 2011); "Was Hayek an Egalitarian?," http://catallaxyf.wordpress.com/2005/07/17/1023/ (accessed May 8, 2011); Don Arthur, "Hayek \& Rawls: An Unlikely Fusion.”; Gamel, "Hayek Et Rawls Sur La Jusice Sociale: Les Différences Sont-Elles Plus Verbales Que Substantielles?”, 97. 
Hayek also offered a specific principle to be used in assessing institutions - the principle of maximizing the chances of success for any person picked out at random, success in satisfying whatever purposes that person may have (II: 114). Hayek has been accused of contradicting himself, at this point. If principles of social justice can't be used to assess the outcomes of the market's spontaneous order, then it should not be possible to assess the market according to the standard of maximizing preference satisfaction, or income. ${ }^{47}$ One response is to claim that when Hayek assesses the market from the perspective outcomes he is talking about desirability, not justice ${ }^{48}$, but this is just a dodge, since Hayek himself concedes that there may be a moral imperative to put in place a minimum income. A more plausible response is to insist that by "distributive justice," Hayek only means distribution according to individual merit.

It is I think misleading to say that Hayek defended a utilitarian principle of institutional assessment. First, I don't think he was really committed to preference satisfaction as the appropriate index to be maximized. Some people may have preferences that are inherently contrary to justice. Everyone may have preferences about what other people should have, which perhaps would lead to a form of double-counting. People may have ideological preferences, i.e. preferences about justice itself, and again, maximizing the aggregate satisfaction of those preferences might not seem like the right way to go. And even

47 "Hayek contradicts his claim that impersonal orders should not be judged against standards of justice by using just such a standard - a utilitarian standard - to justify the paradigm case of a spontaneous order, the market;" Lukes, "Social Justice: The Hayekian Challenge," 74. "The claim that the market generates greater aggregate wealth than any alternative economic order constitutes a prediction about a determinate outcome of a spontaneous order. If the market order can be defended by reference to this particular outcome, it is not evident why other particular outcomes, such as the generation of an equaldistribution of wealth, could not constitute a valid basis for the defense of alternative social arrangements;" David Johnston, "Hayek's Attack on Social Justice," Critical Review 11, no. 1 (1997), 87., or we would have to restrict Hayek's claim about the inapplicability of principles of justice to principles of a particular kind, namely, individually merit-based principles. I discuss the question of whether Hayek's principle is utilitarian below.

48 Edward Feser, "Hayek on Social Justice: Reply to Luke and Johnston," Critical Review 11, no. 4 (1997), 596-97. 
when tidied up in these ways, it is the opportunity for preference satisfaction that we would want to maximize, not preference satisfaction itself, at least if one believes some form of individual freedom and responsibility. Hayek would have accepted many these points. What Hayek is primarily concerned, I think, is opportunity, which could easily be cashed out in a resource-based metric rather than a welfare-based standard. ${ }^{49}$

Second, Hayek sometimes offers the principle of maximizing average expectations as an interpretation of the deeper principle that inequalities ought to benefit everyone. Hayek remarks that "we consent to enforce uniform rules for a procedure which has greatly improved the chances for all to have their wants satisfied, but at the price of all individuals and groups incurring the risk of unmerited failure" (II: 70; emphasis added). Of course we do not individually consent to the basic institutional set-up of our society, even if by collective effort we may succeed in changing it. What Hayek really means is that a system that permits undeserved inequality for the sake of benefiting everyone is just, or at least not unjust. This statement is quite close to Rawls's general conception of justice: "All social values... are to be distributed equally unless an unequal distribution... is to everyone's advantage" (54). Hayek later says that there is "no need morally to justify specific distributions (of income or wealth) which have not been brought about deliberately but are the outcome of a game that is played because it improves the chances of all" (II: 117). There is no need to justify specific distributions arising from interaction within the rules of the economic game, but there is a need to justify the rules themselves, he implicitly concedes, and the appropriate principle to

49 John Gray, Stephen Lukes and David Johnston attribue a utilitarian principle to Hayek, i.e. maximal aggegrate preference satisfaction; John Gray, "Hayek and Classical Liberalism: A Bibliographical Essay."; Lukes, "Social Justice: The Hayekian Challenge," 74; Johnston, "Is the Idea of Social Justice Meaningful?", 613. I agree that Hayek's principle involves maximizing average expectations. I doubt, however, that it is preference satisfaction as opposed to opportunity that is the variable whose average Hayek thinks should be maximized. I also think it is important that Hayek speaks of inequalities benefiting everyone, which is a Rawlsian formulation, but then interprets this idea in terms of maximizing an average. 
use (after that of liberty) is that of maximizing everyone's chances. There is a big gap, however, between inequalities being to everyone's advantage and maximizing the chances of anyone picked out at random.

In one sense, universal benefit means that everyone does better under one set of institutions than they do in some normative baseline, or at least that someone does better while none does worse. But there will exist a large set of different institutional designs that will make some better off and some worse off, and so cannot be ranked by the Pareto criterion. In this situation, Hayek suggests that we choose those institutions that maximize the average; this is what it means to maximize the chances of anyone picked out at random. But maximizing the average could mean that some people will end up with little opportunity while others end up with lots, so long as this maximizes the average. Of course if people voluntarily undertook this gamble before being born, that would be fine. However, if I am born into the lowest social class I will naturally complain that I didn't get a chance to take this gamble. Hayek's response would have to be that for me to have a greater chance some other persons would have had to have a lower chance (and a greater loss of chance than I would gain, since we are assuming that the chosen order maximizes average opportunity). I will then object that such people already have more chance than I do, and still would under the alternate system. Maximizing expected opportunity means being willing to accept that some may have very small chances in life in order that others who already have greater chances can have greater chances still. A more plausible view is that to benefit all, inequalities must benefit those who have less, which was Rawls's view. Hayek admits, at one point, that "it might seem reasonable so to frame laws that they will tend more strongly to improve the opportunities of those whose chances are relatively small." He doesn't deny this claim at the level of principle, but at the level of feasibility. Improving the opportunities of those with 
less "can rarely be achieved by generic rules" (II: 131). Yet this is exactly what income support and public subsidy of education do.

Hayek also had an unfortunate tendency to substitute maximizing aggregate income for maximizing opportunity (II: 130-1). In his Australian lectures, for example, he said that "the productivity-enhancing function of prices... depends on their informing people where they will find their most effective place in the overall pattern of activities - the place in which they are likely to make the greatest contribution to aggregate output. If, therefore, we regard that rule of remuneration as just which contributes as much as possible to increasing the chances of any member of the community picked out at random, we ought to regard the remunerations determined by a free market as the just ones." ${ }^{50}$ The relationship between income and opportunity is convex; earning 100,000 as opposed to 50,000 makes a big difference to the extent of one's opportunities, but earning 1,000,000 as opposed to 950,000 , not nearly as much. Hayek simply cannot leap from maximizing average opportunity to maximizing average income. Hayek himself argued that if one was choosing for one's children, one wouldn't choose an aristocratic society, because chances are one's children wouldn't end up being aristocrats. Instead, one would likely choose "that very type of industrial society which did not offer such delectable plums to the few, but offered better prospects to the great majority" (132). This conclusion might be consistent with maximizing average opportunity, but it is hard to see how it could be consistent with maximizing aggregate income. Who would place their children in a society with a high average income, if in such a society many would be born and grow up in impoverished families and

$50 \quad$ Hayek, Social Justice, Socialism and Democracy, 9-10. Also: "If it were... true that the central direction of the means of production could effect a collective product of at least the same magnitude as that which we now produce, it would indeed be a grave moral problem how this could be done justly. This, however, is not the position, in which we find ourselves. For there is no known way, other than by the distribution of products in a competitive market, to inform individuals in what direction their several efforts 
neighbourhoods?

One reason Hayek didn't worry about these philosophical nuances may have been that he thought that no matter which of the various plausible distributive principles one prefers, a small-state, private property, market society is best. After implausibly arguing that there is no way to help the least well off with generic rules, Hayek goes on to claim that "the fact which... has contributed most during the last two hundred years to increase not only the absolute but also the relative position of those in the lowest income groups has been the general growth of wealth which has tended to raise the income of the lowest groups more than the relatively higher ones" (I: 131). Hayek cites an interesting statistic: a person in the 50th to the 60th percentile of the American income distribution in 1940 who descended to the 30-40 percentile group by 1960 still had a higher absolute income in 1960 than in 1940 . That is no longer the case. It is no longer true that lower deciles in the income distribution are growing faster than higher deciles, so that dropping in the distribution can be consistent with one's income growing. Or to put it another way, it used to be that the incomes of lower parts of the distribution were growing fast enough so that after 20 or 30 years, people in that part of the distribution were making more than the higher ups used to make. No longer. ${ }^{51}$

It is also important to point out that Hayek is thinking about a truncated set of possibilities. The fact that the least well off under a private property free market society do better than under perfect equality does not show that they do as well as they could be doing. The worst off may get more in the unequal distribution of a competitive market economy

must aim to as to contribute as much as possible to the total product;" Hayek, The Fatal Conceit, 7.

51 See for example the U.S. Census bureau's historical income table for families from 1947 to present, which gives the upper limits in 2007 dollars of the quintiles of the income distribution:

http://www.webcitation.org/query?url=http $\% 3 \mathrm{~A} \% 2 \mathrm{~F} \% 2 \mathrm{Fwww} . c e n s u s . g o v \% 2 \mathrm{Fhhes} \% 2 \mathrm{Fwww} \% 2 \mathrm{Fincome} \% 2 \mathrm{Fh}$ istinc\%2Ff01AR.html\&date=2009-04-12. 
than they would in an egalitarian centrally-directed system, ${ }^{52}$ but do they get more in Hayek's ideal society than they would under any feasible liberty-preserving alternative? ${ }^{53}$

The upshot of this discussion is that Hayek's basic philosophical and normative assumptions do not by themselves require or even do much to support his conclusions about law and policy. What generates these conclusions is a set of ambitious empirical claims, in particular claims about feasibility. The most striking example of this occurs in Hayek's rejection of the value of equal opportunity. Hayek accepts formal equality of opportunity, "la carriere ouverte aux talents," and he admits that "there is also much to be said in favour of government providing on an equal basis the means for the schooling of minors," although he doesn't say that this is a requirement of social justice. He then goes on to point out that such measures "would still be very far from creating real equality of opportunity," which would require that government "control the whole physical and human environment of all persons" (II: $84-5) .{ }^{54}$ The obvious response to this claim is that even if $100 \%$ equal opportunity would require a totalitarian state, it is a principle of justice that we attempt to achieve fair equal opportunity up to the point at which it threatens personal liberty. At this point Hayek has recourse to the slippery slope. The more government succeeds in equalizing opportunities, the stronger becomes the demand that remaining handicaps must be removed. "This would go on until government literally controlled every circumstance which could affect any person's well-being." Thus "any attempt" to realize equality of opportunity beyond government provision of services that can be justified on other grounds "is apt to produce a

52 Hayek, Social Justice, Socialism and Democracy, 14.

$53 \quad$ Hayek might admit all of this but say that it doesn't have anything to do with social justice.

Maximizing opportunity makes a society more desirable, in his words, but not necessarily more just; c.f. Tebble, "Hayek and Social Justice: A Critique," 592. But the decisions we make about our social rules and institutions are things we do to and with one another, and they give rise to public agencies that do things to people, e.g. that enforce rules of property and contract. Such decisions and their results are forms of interpersonal conduct that can be just or unjust.

$54 \quad$ See also Hayek, The Constitution of Liberty, 92-93. 
nightmare" (II: 84-5; see also 137-42 "floodgates"). ${ }^{55}$ The claim that the political slippery slope presents us with an either / or choice between personal liberty and equality of opportunity is not convincing. ${ }^{56}$

\section{6. $\quad$ Remaining Differences}

At the level of fundamental principle, therefore, Hayek is in many ways an egalitarian

liberal. There are two important respects, however, in which Rawls's view is more egalitarian than Hayek's at the level of principle. The first has to do with the importance of equal political liberty in the first principle.

Rawls was aware of the possibility that inequalities satisfying the difference principle might be so great as to undermine the fair value of political liberties $(197-8 ; 247)$. He was concerned that unless we take steps to limit the extent of socio-economic inequality or insulate the political process from such inequality, those more advantaged will come to control the society, despite the formal equality of the electoral system. Hayek was much less worried about this possibility. Hayek was worried that those who lose in market competition who be tempted to use the power of the state to recoup their losses, and so interfere with the mechanisms of the market. He argued that such conduct was unprincipled. ${ }^{57}$ He expressed much less worry that wealthy individuals and corporations would use their extra political influence to change the rules of the game in their favour, not by eliminating the market but

55 See also Hayek, The Constitution of Liberty, 100.

56 Hayek has another, even less plausible argument against state action in service of fair equality of opportunity, which is that it will reduce the incentive parents face to work hard, and make maximally productive decisions, so as to be able to pass on wealth to their children; Hayek, Social Justice, Socialism and Democracy, 11. Here, Hayek seems to be saying that we should not sacrifice any bit of aggregate wealth for the sake of fair equality of opportunity.

57 Hayek believed that the Great Society required a particular moral attitude, namely, one in which one competes honestly according to the rules of the economic game, "guided only by the abstract signals of prices and giving no preferences because of their sympathies or views on the merits of those whom they deal;" Hayek, Social Justice, Socialism and Democracy, 13. 
my shaping it, and the way it is regulated, or not regulated.

The second remaining difference concerns the idea that we ought to maximize the lowest social position. The lexical difference principle looks like a very strict form of prioritarianism $^{58}$ : first maximize with respect to the worst off, then the second worst off, then the third. However, this maximization was only to take place within one generation. The idea was that inequality between positions now should raise (or at least not lower) the lower position compared to what it could otherwise have been, not that inequality now may be justified because it raises the worst off in the long run. There is no need to go on maximizing indefinitely. Except where development is necessary for realizing equal basic liberties, justice doesn't require that the least well off accept more inequality today for the sake of maximizing the level of the lowest position in the long run, as might be the case for a prioritarian principle applied intergenerationally. The focus of Rawls's principle is how we divide what we produce together today - equally, unless an unequal division benefits alls.

\section{Conclusion}

Having argued that Haeyk is a closet Rawlsian / egalitarian liberal who reaches inegalitarian conclusions only via equivocation and implausible empirical claims, what remains of distinctive value in Hayek's writings about social justice?

From the left, markets are sometimes viewed as being inherently objectionable, because they involve people callously using each other for selfish gain, but to be tolerated

58 Prioritarianism captures certain seemingly egalitarian intuitions without being vulnerable to the levelling down objection. In some cases, a more equal distribution can seem better than less equal distributions in which people are on average better off; compare 145, 145 to 100, 200. Yet many people believe that more equal distribution is in no way better if it simply makes the better off worse off, without benefiting anyone; compare 100, 200 to 100, 100. Prioritarianism solves this problem by arguing that well-being or opportunity is all that matters, not relative position, but well-being matters more the less one has of it; Derek Parfit, "Equality and Priority," Ratio 10, no. 3 (1997): 202-21. 
despite this injustice, to the extent that they make everyone better off. ${ }^{59}$ One lesson Hayek has to teach us, perhaps, is that markets and private property rights are important not just because they are efficient at producing wealth, but because they involve people with very different values and purposes managing to cooperate in generally beneficial ways, despite their many disagreements about how society ought to allocate its resources. And they involve all of us exploring on a decentralized, trial-and-error basis the great many different ways there are of producing the things we want or might discover we want. The value in this process is not just in generating greater material wealth but in permitting and indeed encouraging attempts at different ways of living. Of course there is a lot of mindless consumerism and conformity in mass markets. But it would be a mistake to ignore the tremendous creativity and innovation that markets and private property permit. Experiments in living also require experiments in producing. ${ }^{60}$

59 The view I have in mind here is G. A. Cohen's, as reflected in his comments about how capitalism "corrupts humanity," in the envoi to his If You're An Egalitarian, How Come You're So Rich? After many years of service at a dress-making factory, Cohen's father was abruptly dismissed, simply because maximizing shareholder profit required it. Cohen uses this incident to illustrate the way in which "business turns human producers into commodities"; G. A. Cohen, If You'Re an Egalitarian, How Come You'Re So Rich? (Cambridge, Mass.: Harvard University Press, 2000), 181.

60 Joseph Carens has argued that a socialist society could make use of the market's virtues - aggregating dispersed information about preferences and resources, as well as exploring the myriad conceivable production possibilities - while taxing earnings at a $100 \%$ rate and redistributing income according to principles of justice, if citizens were motivated by a moral duty to contribute to society, i.e. to make career decisions so as to maximize their pre-tax income; Joseph H. Carens, Equality, Moral Incentives, and the Market: An Essay in Utopian Politico-Economic Theory (Chicago Originals) (University of Chicago Press, 1981). As Carens came to recognize, however, any such social duty could only plausibly be a duty to make some reasonable degree of contribution, not to maximize pre-tax earnings; Joseph H. Carens, "Rights and Duties in an Egalitarian Society," Political Theory 14, no. 1 (1986), 35-36. However, as soon as we allow people the moral freedom to pursue not only their own personal interests but their own religious, philosophical, and ideological goals, the need for incentives will reappear, if the market is to work its information-aggregation and possibility-exploration magic. 